\title{
Circulating long noncoding RNAs as potential biomarkers for stomach cancer: A systematic review and meta- analysis
}

\section{Fang Cao}

First Peoples Hospital of Kunshan

\section{Yongwei Hu}

First Peoples Hospital of Kunshan

\section{Zaichang Chen}

First Peoples Hospital of Kunshan

\section{Wei Han}

First Peoples Hospital of Kunshan

\section{Weijie Lu}

First Peoples Hospital of Kunshan

Jianhao Xu ( $\sim$ xu_jianhao@hotmail.com )

First Peoples Hospital of Kunshan https://orcid.org/0000-0002-2064-4597

Houzhong Ding

First Peoples Hospital of Kunshan

\section{Xiaojun Shen}

First Peoples Hospital of Kunshan

\section{Research}

Keywords: stomach cancer, circulating IncRNAs, diagnosis, meta-analysis.

Posted Date: February 8th, 2021

DOI: https://doi.org/10.21203/rs.3.rs-81358/v2

License: (c) (i) This work is licensed under a Creative Commons Attribution 4.0 International License. Read Full License

Version of Record: A version of this preprint was published on March 26th, 2021. See the published version at https://doi.org/10.1186/s12957-021-02194-6. 


\section{Abstract}

Background: Recent researches have suggested that long noncoding RNA (IncRNA) is involved in the tumorigenesis and development of stomach cancer (SC). This meta-analysis aimed to identify the diagnostic performance of circulating IncRNAs in SC.

Methods: All relevant studies were systematically searched through PubMed, Web of Science, Cochrane Library and EMBASE databases. The diagnostic values of IncRNAs were mainly assessed by pooled sensitivity, specificity, and summary receiver operating characteristic area under the curve (SROC AUC). Meta-DiSc 1.4, Review Manager 5.3 and STATA 12.0 were used for statistical analysis.

Results: A total of 42 eligible studies were included in this meta-analysis. The pooled sensitivity, specificity, and SROC AUC were 0.78 (95\% Cl: 0.75-0.81), 0.75 (95\% Cl: 0.71-0.78), and 0.83 (95\% Cl: 0.80-0.86) respectively, suggesting that the IncRNAs test had a high accuracy for the diagnosis of SC. Obvious heterogeneity might come from the type of IncRNA through subgroup and meta-regression analysis. Fagan diagram shows the clinical value of IncRNAs test in SC.

Conclusions: Abnormal expression of circulating IncRNAs exhibits a high efficacy for diagnosing SC, which is promising in clinical application.

\section{Background}

Based on 2018 global cancer data, stomach cancer (SC) is the 5th most common neoplasm and the 3rd most deadly cancer, causing an estimated 783,000 deaths in 2018. ${ }^{[1]}$. Studies have shown that SC patients are often diagnosed at later stages due to the absence of typical early signs ${ }^{[2]}$. As a result, the overall survival in patients with advanced $\mathrm{SC}$ is poor; the 5 -year survival rate ranges from approximately $10 \%$ to $30 \%{ }^{[3]}$. The prognosis of SC is highly dependent on the timing of the diagnosis ${ }^{[4]}$. Blood-based cancer biomarkers are ideal for screening and early detection due to their convenience and low invasiveness. However, the low sensitivity and specificity of conventional blood biomarkers limit their application, such as carcinoembryonic antigen and carbohydrate antigen 19-9[5]. Although considerable effort has been devoted to identifying the underlying mechanism of SC, the identification of new diagnostic markers for SC is still a considerable challenge.

In recent years, the regulation of gene expression by noncoding RNAs has been studied thoroughly. Long noncoding RNA (IncRNAs) are RNA molecules greater than 200 nucleotides that modulate gene expression at the levels of transcription, posttranscription and translation, but are not able to encode proteins ${ }^{[6]}$. An increasing body of evidence has suggested that IncRNAs play a major role during the processes of tumorigenesis and development, which may offer new ideas for the early diagnosis of SC. For instance, for distinguishing SC patients from normal subjects, the IncRNAs PCGEM1 and LOC80054 have higher area under the curve (AUC) values than other conventional tumor markers (AFP, CEA, CA12-5, CA19-9 and CA72-4) ${ }^{[7,8]}$. Similarly, IncRNAs can also be detected in blood, and circulating noncoding RNAs have become a new source of noninvasive cancer biomarkers ${ }^{[9]}$, which can serve as new diagnostic biomarkers for SC.

However, considering the small sample size and limitations of the research design, there is insufficient evidence to confirm the diagnostic accuracy of circulating IncRNAs in SC patients. To address this shortcoming, a comprehensive systematic review and meta-analysis was conducted to explore the diagnostic roles of circulating IncRNAs in SC. 


\section{Methods}

\section{Search strategy}

This meta-analysis was conducted in accordance with the Preferred Reporting Items for Systematic Reviews and Meta-Analyses guidelines ${ }^{[10]}$. The PubMed, Web of Science, Cochrane Library, and Embase databases were systematically searched for potentially relevant articles, which were independently screened by two authors (Cao $\mathrm{F}$ and $\mathrm{Xu} \mathrm{J}$ ). The references lists of relevant meta-analyses and reviews were also searched to identify articles that were not included in the initial search. In addition, relevant articles in scientific congresses and conferences were reviewed. The search strategy and Participant, Index test, Comparison, Outcome, and Study (PICOS) design strategy are shown in Table 1. The publication search was updated regularly until July 9, 2020.

Table 1. Systematic search strategy (PICOS strategy).

\begin{tabular}{|c|c|}
\hline \multicolumn{2}{|c|}{ Search strategy } \\
\hline Participant & 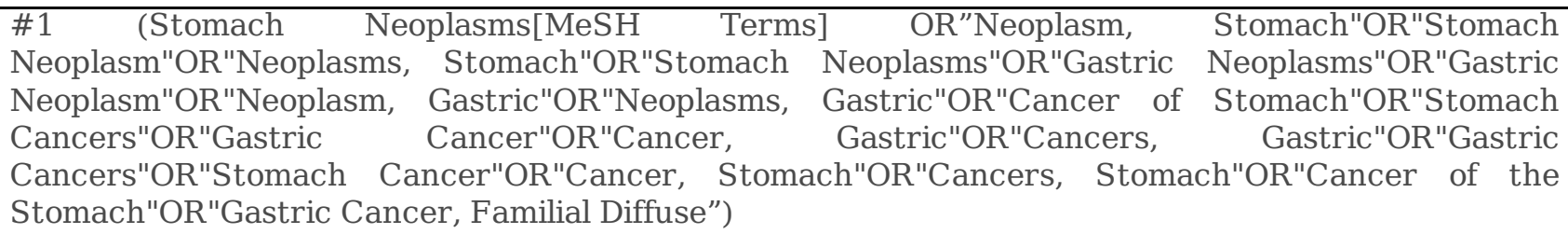 \\
\hline Index test & $\begin{array}{l}\text { \#2 (RNA, Long Noncoding[MeSH Terms]OR "RNA, Long Noncoding"OR"Noncoding RNA, } \\
\text { Long"OR"lncRNA"OR"Long ncRNA"OR"ncRNA, Long"OR"RNA, Long Non-Translated"OR"Long } \\
\text { Non-Translated RNA"OR"Non-Translated RNA, Long"OR"RNA, Long Non Translated"OR"Long Non- } \\
\text { Coding RNA"OR"Long Non Coding RNA"OR”Non-Coding RNA, Long"OR"RNA, Long Non- } \\
\text { Coding"OR"Long Non-Protein-Coding RNA"OR"Long Non Protein Coding RNA"OR"Non-Protein- } \\
\text { Coding RNA, Long"OR"RNA, Long Non-Protein-Coding"OR"Long Noncoding RNA"OR"RNA, Long } \\
\text { Untranslated"OR"Long Untranslated RNA"OR"Untranslated RNA, Long"OR"Long } \\
\text { ncRNAs"OR"ncRNAs, Long"OR"Long Intergenic Non-Protein Coding RNA"OR"Long Intergenic Non } \\
\text { Protein Coding RNA"OR"LincRNAs"OR"LINC RNA") }\end{array}$ \\
\hline Comparison & None \\
\hline Outcome & 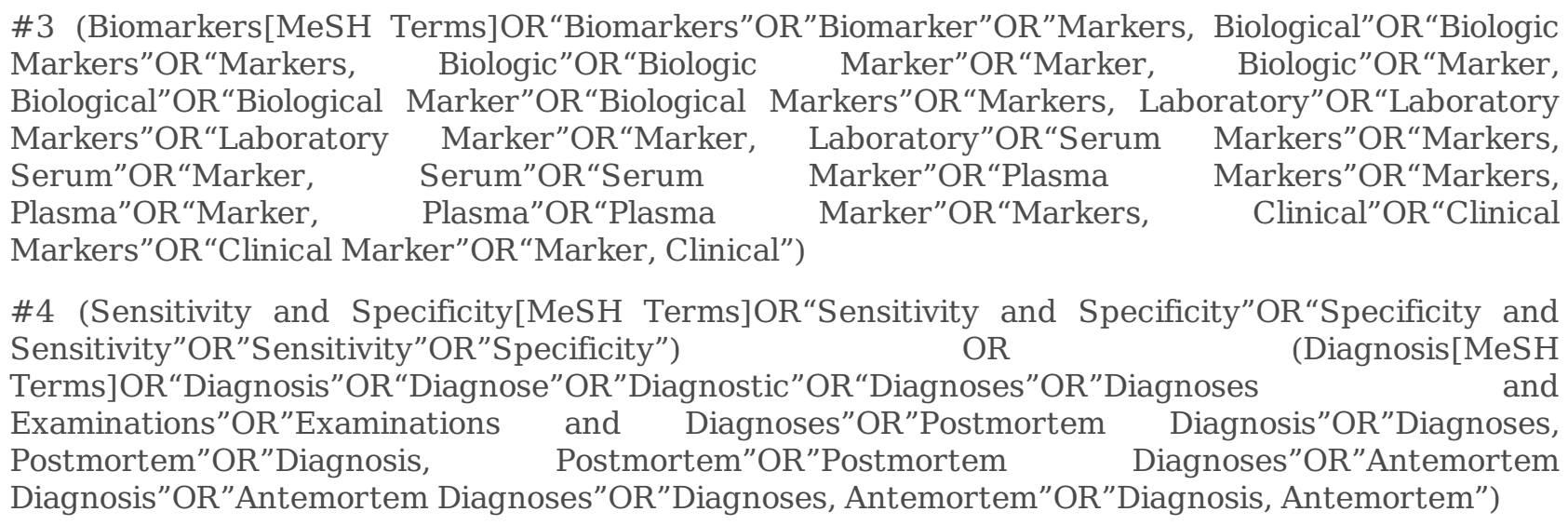 \\
\hline $\begin{array}{l}\text { Study } \\
\text { design }\end{array}$ & None \\
\hline Search & \#1 AND \#2 AND (\#3 OR \#4) \\
\hline Database s & \\
\hline Language & No restriction \\
\hline $\begin{array}{l}\text { Electronic } \\
\text { databases }\end{array}$ & PubMed, Web of Science, Cochrane Library, and Embase databases \\
\hline
\end{tabular}




\section{Selection criteria}

The following inclusion criteria were used:

(i) The expression of IncRNAs was determined in plasma or serum by quantitative reverse transcription-polymerase chain reaction or other molecular techniques;

(ii) Study on the relationship between IncRNA expression levels and cancer diagnosis;

(iii) Sufficient data to determine false negatives, true negatives, false positives and true positives.

The exclusion criteria were as follows:

(i) Duplicate publications;

(ii) Meta-analysis, correspondence, single case reports, review articles and animal model studies.

Data extraction

The two authors (Cao F and $\mathrm{Xu} \mathrm{J}$ ) reviewed the full texts and independently extracted data from all included studies. The following data were extracted: first author, year of publication, race of participants, pathological type of experimental group/control group, sample size, specimen type, IncRNA type, dysregulated state of IncRNAs, sensitivity and specificity.

\section{Quality assessment}

Two authors ( $\mathrm{Xu} \mathrm{J}$ and Cao F) independently evaluated the quality of each diagnostic study. The methodological quality and applicability of the included studies were examined using the Quality Assessment of Diagnostic

Accuracy Studies 2 (QUADAS-2) ${ }^{[11]}$ tool in using Review Manager software version 5.3. The QUADAS-2 tool is used to assess the quality of diagnostic accuracy studies ${ }^{[11]}$. The QUADAS-2 tool contains 4 main areas: process and timing, index testing, reference standards, and patient selection. The risk of prejudice and apprehension were classified as "low", "high" or "unclear". The differences were resolved through discussions among all the researchers.

\section{Statistical analysis}

Meta-analyses were performed using Meta-DiSc 1.4 (Romany Cajal Hospital, Madrid, Spain) ${ }^{[12]}$, Review Manager 5.3 (Cochrane Collaboration, Oxford, England), and STATA 12.0 (Stata Corp LP, TX, USA).

For a meta-analysis of diagnosis, the sensitivity, specificity, negative likelihood ratio, positive likelihood ratio, diagnostic odds ratio and the corresponding 95\% Cls were used to determine the diagnostic value of IncRNAs. To quantitatively assess the accuracy of diagnosis, the area under the curves (AUCs) of summary receiver operating characteristic curves (SROCs) were determined. A hierarchical summary receiver operator characteristic (HSROC) model was adopted to extend the fixed-effects SROC model and evaluate the accuracy of multiple diagnostic tests.

The heterogeneity tests were carried out by the Q-test and $\mathrm{I}^{2}$ statistics. P values of $<0.05$ were regarded as statistically significant. An $\mathrm{I}^{2}$ value $>50 \%$ and a $\mathrm{P}$ value $<0.05$ indicated significant heterogeneity between the included studies, and a random effects model was applied. Otherwise, if there was no obvious heterogeneity, the fixed effects model was applied to evaluate the aggregated results. The heterogeneity induced by the threshold 
effect was evaluated by the ROC plane. Galbraith Star charts and bivariate boxplots were employed to estimate the degree of heterogeneity. Subgroup analysis and meta-regression were used to assess the source of heterogeneity. Subgroup results were examined one at a time.

Sensitivity analysis was used to determine the stability of the results. Potential publication bias was examined by Deeks' funnel plot. A P-value of $>0.1$ indicates that there is no publication bias. Fagan's nomogram was applied to judge the clinical value of IncRNAs as a diagnostic method.

\section{Results}

\section{Literature searching and study screening}

In total, 1867 articles were obtained from the four databases. After eliminating 639 duplicate articles, 1228 studies were further screened. After screening the titles, abstracts, and full texts, 42 eligible studies ${ }^{[2,7,13-52]}$ were finally included based on the selection criteria (Fig 1).

\section{Quality evaluation and main characteristics of the eligible studies}

The diagnostic meta-analysis analyzed 42 eligible studies $^{[2,7,13-52]}$ published between 2013 and 2020. Thirty-seven studies detected IncRNA expression in Asian population, while 5 studies detected IncRNA expression in Caucasian populations. Sample types included plasma, serum, and plasma/serum exosomes. All SC patients were pathologically confirmed, and the control groups consisted of healthy donor individuals and benign stomach disease patients. A total of 49 different IncRNAs were examined across all included studies; most of the IncRNAs were upregulated in SC (Table 2). The quality assessment is shown in Fig 2.

Table 2. Main characteristics of eligible studies for diagnosis. 


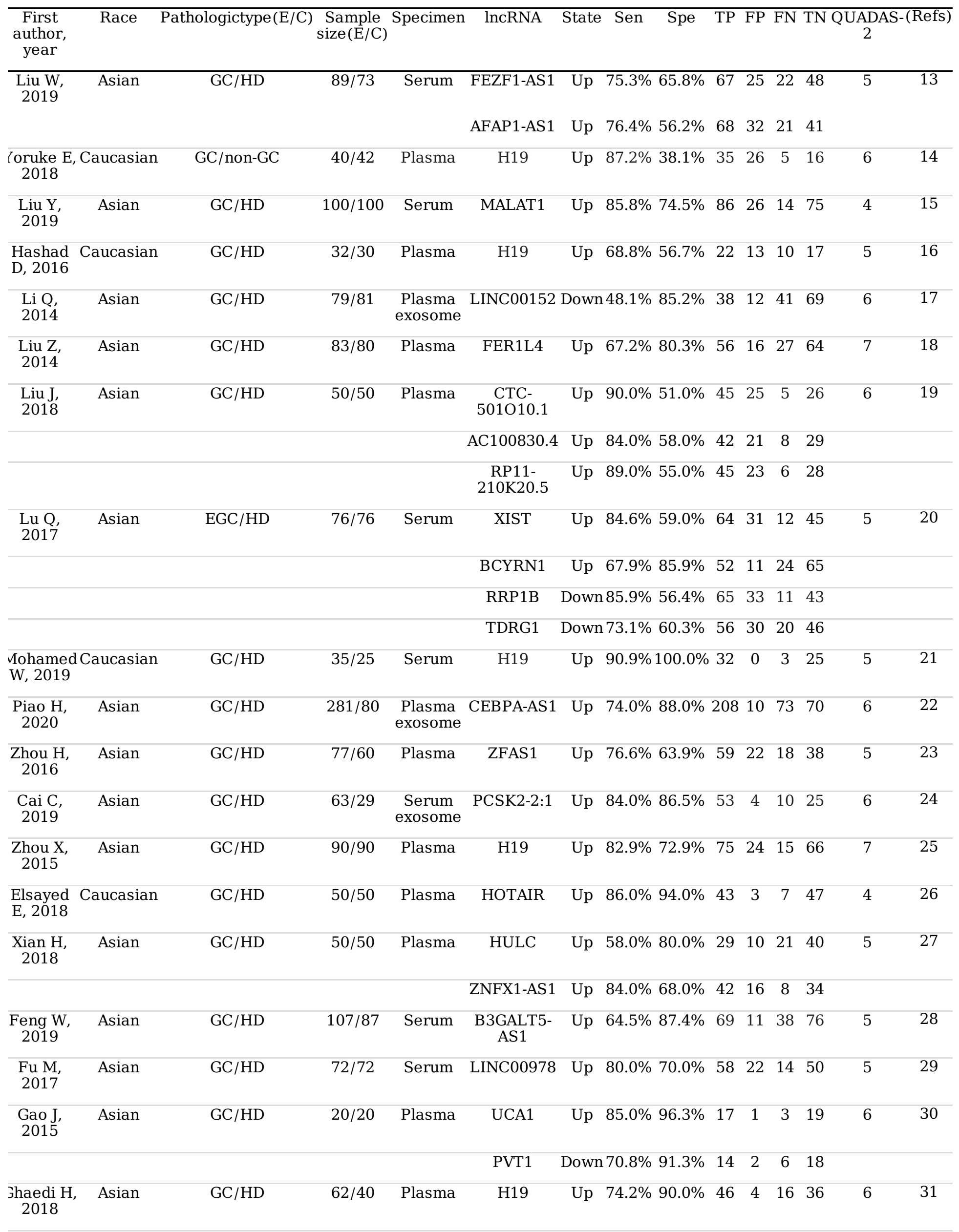


MEG3 Down 77.4\% 52.5\% $48 \quad 19 \quad 14 \quad 21$

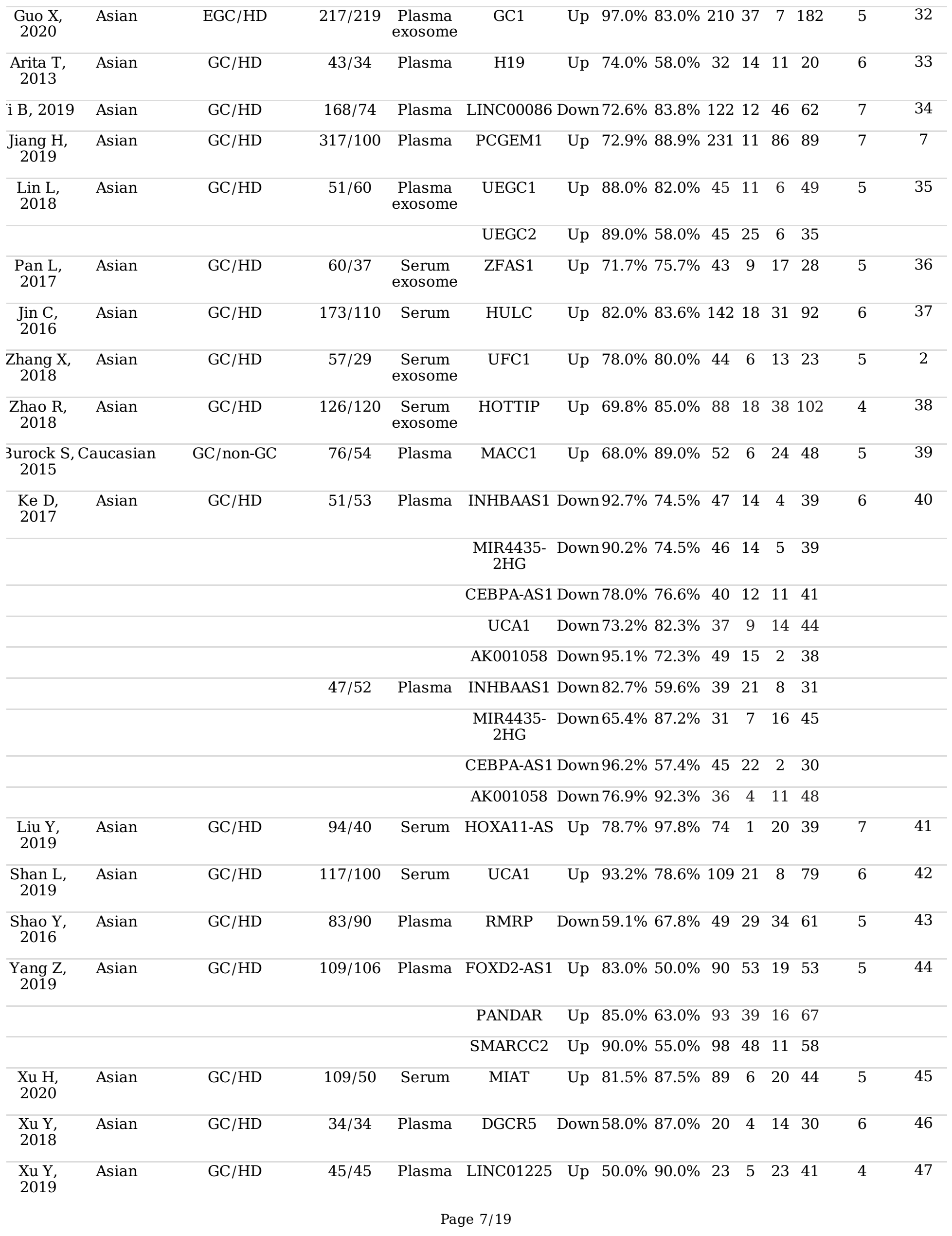




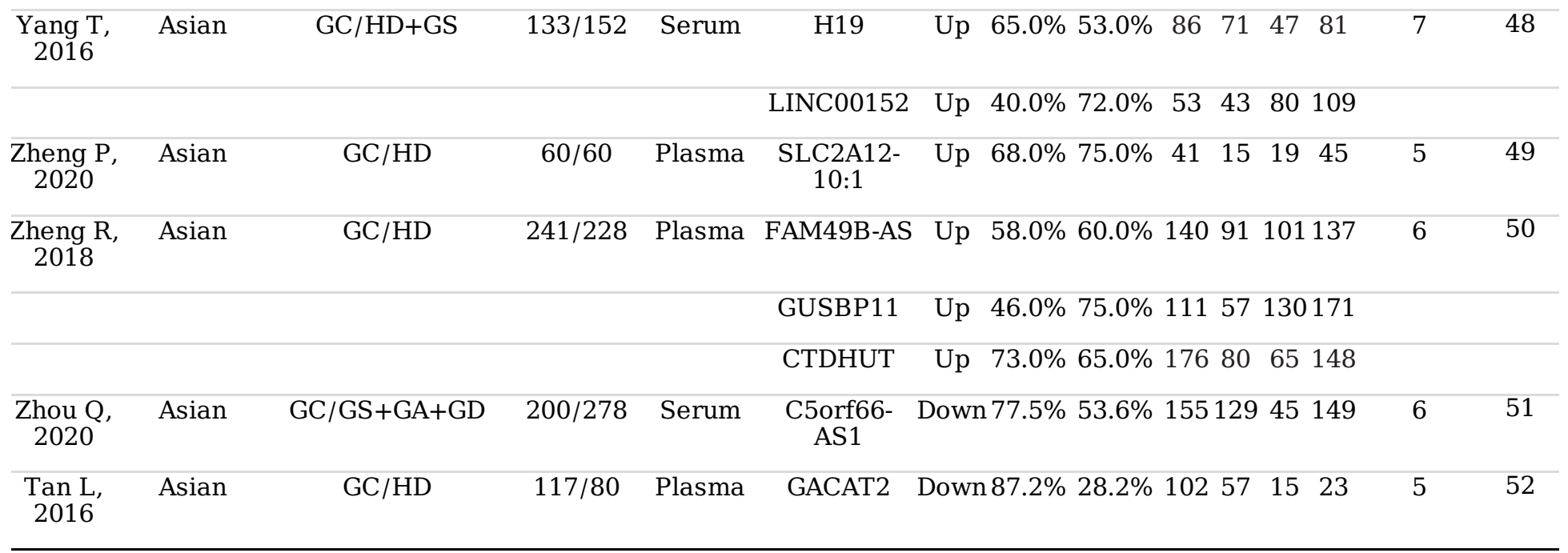

Note: E/C: experimental group/control group; GC: gastric cancer; EGC: early gastric cancer; HD: healthy donor individuals; GS: superficial gastritis; GA: atrophic gastritis; GD: gastric dysplasia; SEN: sensitivity; SPE: specificity; TP: true positive; FP: false positive; FN: false negative; TN: true negative; QUADAS-2: Quality Assessment of Diagnostic Accuracy Studies 2.

\section{Diagnostic accuracy of IncRNA}

A total of 42 eligible diagnostic studies were meta-analyzed. As illustrated in Fig 3, the pooled sensitivity, specificity, positive likelihood ratio, negative likelihood ratio, and diagnostic odds ratio were 0.78 (95\% Cl: 0.75-0.81), 0.75 (95\% Cl: 0.71-0.78), 3.09 (95\% Cl: 2.66-3.58), 0.29 (95\% Cl: 0.25-0.33), and 10.67 (95\% Cl: 8.34-13.65), respectively. As demonstrated in Fig 4A, the AUC value of the SROC was 0.83 (95\% Cl: 0.80-0.86). The SROC results were further evaluated through the HSROC model. As shown in Fig 4B, the $\beta$ estimate was 0.11 (95\% Cl: $-0.19-0.40)$ and the corresponding $\mathrm{P}$ value was 0.485 . The lambda estimate was 2.38 (95\% Cl: 2.13-2.63).

\section{Heterogeneity analysis}

As illustrated in Fig 3, obvious heterogeneity was found in the pooled sensitivity $\left(\mathrm{I}^{2}=88.93 \%, \mathrm{P}<0.01\right)$, specificity $\left(\mathrm{I}^{2}\right.$ $=88.14 \%, \mathrm{P}<0.01)$, positive likelihood ratio $\left(\mathrm{I}^{2}=88.49 \%, \mathrm{P}<0.01\right)$, negative likelihood ratio $\left(\mathrm{I}^{2}=88.71 \%, \mathrm{P}<0.01\right)$, and diagnostic odds ratio $\left(\mathrm{I}^{2}=100.00 \%, \mathrm{P}<0.01\right)$.

A nontypical shoulder arm appearance was observed in the ROC plane (Fig 5A). Twenty out of the 63 studies of the Galbraith star chart and 10 out of 42 studies of the bivariate box plot fell outside the 95\% Cl (Fig 5B and 5C). Fig 5D shows the meta-regression forest map. All studies were grouped according to race, pathological types of experimental groups, pathological types of control groups, sample size, specimen type, dysregulated state of IncRNAs, and IncRNA types. Table 3 shows the changes in sensitivity, specificity, and $I^{2}$ values after meta-regression and subgroup analysis.

Table 3. Subgroup analysis of the diagnostic efficacy of lncRNA in stomach cancer. 


\begin{tabular}{|c|c|c|c|c|c|c|c|c|c|}
\hline \multirow{2}{*}{$\begin{array}{l}\text { Group } \\
\text { Overall }\end{array}$} & \multirow[t]{2}{*}{ Subgroup } & \multirow{2}{*}{$\begin{array}{l}\begin{array}{l}\text { No. of } \\
\text { studies }\end{array} \\
42\end{array}$} & \multirow{2}{*}{$\begin{array}{l}\begin{array}{l}\text { No. of } \\
\text { patients }\end{array} \\
7524\end{array}$} & \multirow{2}{*}{$\begin{array}{l}\text { Sensitivity } \\
0.78[0.75, \\
0.81]\end{array}$} & \multicolumn{4}{|c|}{$\begin{array}{l}\text { Heterogeneity Specificity Heterogeneity AUC } \\
\begin{array}{ll}\left.\mathrm{I}^{2} ; \mathrm{P} \text { value }\right) & \left(\mathrm{I}^{2} ; \mathrm{P} \text { value }\right)\end{array}\end{array}$} & \multirow[t]{2}{*}{$\begin{array}{l}\text { Meta- } \\
\text { regression } \\
\text { (P value) }\end{array}$} \\
\hline & & & & & $\begin{array}{l}88.93 \% \\
<0.001\end{array}$ & $\begin{array}{l}0.75[0.71, \\
0.78]\end{array}$ & $\begin{array}{l}88.14 \% \\
<0.001\end{array}$ & $\begin{array}{l}0.83 \\
{[0.80-} \\
0.86]\end{array}$ & \\
\hline \multirow[t]{2}{*}{ Race } & Asian & 60 & 7090 & $\begin{array}{l}0.78[0.75, \\
0.81]\end{array}$ & $\begin{array}{l}89.38 \% \\
<0.001\end{array}$ & $\begin{array}{l}0.74[0.70, \\
0.77]\end{array}$ & $\begin{array}{l}87.51 \% \\
<0.001\end{array}$ & $\begin{array}{l}0.83 \\
{[0.79-} \\
0.86]\end{array}$ & 0.48 \\
\hline & Caucasian & 5 & 434 & $\begin{array}{l}0.81[0.70, \\
0.89]\end{array}$ & $\begin{array}{l}75.16 \% \\
<0.001\end{array}$ & $\begin{array}{l}0.86[0.52, \\
0.97]\end{array}$ & $\begin{array}{l}94.22 \% \\
<0.001\end{array}$ & $\begin{array}{l}0.87 \\
{[0.84-} \\
0.90]\end{array}$ & 0.48 \\
\hline \multirow[t]{2}{*}{$\begin{array}{l}\text { Pathologic } \\
\text { types(E) }\end{array}$} & GC & 60 & 6936 & $\begin{array}{l}0.78[0.74, \\
0.81]\end{array}$ & $\begin{array}{l}88.19 \% \\
<0.001\end{array}$ & $\begin{array}{l}0.75[0.71, \\
0.79]\end{array}$ & $\begin{array}{l}88.35 \% \\
<0.001\end{array}$ & $\begin{array}{l}0.83 \\
{[0.80-} \\
0.86]\end{array}$ & 0.38 \\
\hline & EGC & 5 & 588 & $\begin{array}{l}0.85[0.72, \\
0.93]\end{array}$ & $\begin{array}{l}91.39 \% \\
<0.001\end{array}$ & $\begin{array}{l}0.71[0.58, \\
0.81]\end{array}$ & $\begin{array}{l}90.27 \% \\
<0.001\end{array}$ & $\begin{array}{l}0.84 \\
{[0.80-} \\
0.87]\end{array}$ & 0.38 \\
\hline \multirow[t]{3}{*}{$\begin{array}{l}\text { Pathologic } \\
\text { types (C) }\end{array}$} & health & 61 & 6549 & $\begin{array}{l}0.79[0.75, \\
0.82]\end{array}$ & $\begin{array}{l}89.32 \% \\
<0.001\end{array}$ & $\begin{array}{l}0.75[0.71, \\
0.79]\end{array}$ & $\begin{array}{l}86.53 \% \\
<0.001\end{array}$ & $\begin{array}{l}0.84 \\
{[0.80-} \\
0.87]\end{array}$ & 0.15 \\
\hline & non-GC & 2 & 212 & - & - & - & - & - & 0.86 \\
\hline & GS & 2 & 763 & - & - & - & - & - & 0.10 \\
\hline \multirow[t]{3}{*}{ Sample size } & $\mathrm{N} \leq 100$ & 21 & 1153 & $\begin{array}{l}0.79[0.74, \\
0.84]\end{array}$ & $\begin{array}{l}74.67 \% \\
<0.001\end{array}$ & $\begin{array}{l}0.77[0.69, \\
0.84]\end{array}$ & $\begin{array}{l}84.82 \% \\
<0.001\end{array}$ & $\begin{array}{l}0.85 \\
{[0.82-} \\
0.88]\end{array}$ & 0.62 \\
\hline & $100<\mathrm{N} \leq 200$ & 28 & 2722 & $\begin{array}{l}0.79[0.74, \\
0.82]\end{array}$ & $\begin{array}{l}79.14 \% \\
<0.001\end{array}$ & $\begin{array}{l}0.74[0.68, \\
0.79]\end{array}$ & $\begin{array}{l}85.75 \% \\
<0.001\end{array}$ & $\begin{array}{l}0.83 \\
{[0.80-} \\
0.86]\end{array}$ & 0.95 \\
\hline & $\mathrm{N}>200$ & 16 & 3649 & $\begin{array}{l}0.77[0.68, \\
0.84]\end{array}$ & $\begin{array}{l}95.41 \% \\
<0.001\end{array}$ & $\begin{array}{l}0.73[0.65, \\
0.79]\end{array}$ & $\begin{array}{l}92.57 \% \\
<0.001\end{array}$ & $\begin{array}{l}0.81 \\
{[0.77-} \\
0.84]\end{array}$ & 0.58 \\
\hline \multirow[t]{3}{*}{ Specimen } & Plasma & 23 & 3467 & $\begin{array}{l}0.78[0.74, \\
0.82]\end{array}$ & $\begin{array}{l}87.25 \% \\
<0.001\end{array}$ & $\begin{array}{l}0.72[0.67, \\
0.77]\end{array}$ & $\begin{array}{l}86.87 \% \\
<0.001\end{array}$ & $\begin{array}{l}0.82 \\
{[0.79-} \\
0.85]\end{array}$ & 0.34 \\
\hline & Serum & 12 & 2468 & $\begin{array}{l}0.78[0.72, \\
0.83]\end{array}$ & $\begin{array}{l}90.56 \% \\
<0.001\end{array}$ & $\begin{array}{l}0.75[0.67, \\
0.82]\end{array}$ & $\begin{array}{l}90.37 \% \\
<0.001\end{array}$ & $\begin{array}{l}0.84 \\
{[0.80-} \\
0.87]\end{array}$ & 0.99 \\
\hline & Exosome & 8 & 1589 & $\begin{array}{l}0.81[0.70, \\
0.89]\end{array}$ & $\begin{array}{l}92.18 \% \\
<0.001\end{array}$ & $\begin{array}{l}0.81[0.76, \\
0.86]\end{array}$ & $\begin{array}{l}69.40 \% \\
<0.001\end{array}$ & $\begin{array}{l}0.87 \\
{[0.84-} \\
0.90]\end{array}$ & 0.17 \\
\hline \multirow[t]{2}{*}{$\begin{array}{l}\text { Dysregulated } \\
\text { state }\end{array}$} & Upregulated & 46 & 6003 & $\begin{array}{l}0.78[0.74, \\
0.82]\end{array}$ & $\begin{array}{l}90.19 \% \\
<0.001\end{array}$ & $\begin{array}{l}0.75[0.71, \\
0.80]\end{array}$ & $\begin{array}{l}87.40 \% \\
<0.001\end{array}$ & $\begin{array}{l}0.84 \\
{[0.80-} \\
0.87]\end{array}$ & 0.78 \\
\hline & Downregulate & $d 19$ & 1521 & $\begin{array}{l}0.79[0.72, \\
0.84]\end{array}$ & $\begin{array}{l}84.54 \% \\
<0.001\end{array}$ & $\begin{array}{l}0.72[0.64, \\
0.79]\end{array}$ & $\begin{array}{l}89.12 \% \\
<0.001\end{array}$ & $\begin{array}{l}0.82 \\
{[0.79} \\
0.86]\end{array}$ & 0.78 \\
\hline \multirow[t]{3}{*}{ lncRNA } & H19 & 7 & 848 & $\begin{array}{l}0.78[0.70, \\
0.84]\end{array}$ & $\begin{array}{l}75.98 \% \\
<0.001\end{array}$ & $\begin{array}{l}0.72[0.49, \\
0.88]\end{array}$ & $\begin{array}{l}89.62 \% \\
<0.001\end{array}$ & $\begin{array}{l}0.82 \\
{[0.78-} \\
0.85]\end{array}$ & 0.69 \\
\hline & UCA1 & 3 & 361 & $\begin{array}{l}0.87[0.81, \\
0.91]\end{array}$ & $83.60 \% ; 0.02$ & $\begin{array}{l}0.82[0.76, \\
0.88]\end{array}$ & $\begin{array}{l}45.20 \% \\
0.161\end{array}$ & $\begin{array}{l}0.92 \\
{[0.84-} \\
0.99]\end{array}$ & 0.13 \\
\hline & CEBPA-AS1 & 3 & 564 & $\begin{array}{l}0.77[0.73, \\
0.81]\end{array}$ & $\begin{array}{l}86.00 \% \text {; } \\
0.001\end{array}$ & $\begin{array}{l}0.76[0.69, \\
0.82]\end{array}$ & $\begin{array}{l}86.80 \% \\
0.001\end{array}$ & $\begin{array}{l}0.88 \\
{[0.84-} \\
0.92]\end{array}$ & 0.63 \\
\hline
\end{tabular}


Note: E/C: experimental group/control group; GC: gastric cancer; EGC: early gastric cancer; HD: healthy donor individuals; GS: superficial gastritis; AUC, area under the curve.

\section{Sensitivity analysis and publication bias}

First, sensitivity analysis was carried out to determine the stability of our results. The removal of individual studies exhibited no noticeable changes in pooled results (Additional file 1: Supplementary Figure 1, Fig. S1A). The P value of Deeks' funnel plot asymmetry test was 0.12 (Additional file 1: Supplementary Figure 1, Fig. S1B).

\section{Clinical values of IncRNAs for SC diagnosis}

As shown in Fig 6, Fagan's nomogram revealed that if the patient had a positive IncRNA test result, the actual probability of suffering from SC was $76 \%$, while the probability was $22 \%$ if a negative test result was obtained.

\section{Discussion}

In recent years, IncRNAs have been recognized as potential diagnostic biomarkers for different cancers ${ }^{[53]}$. As a diagnostic biomarker for cancer, IncRNAs have the following special advantages. First, the abundance of IncRNAs is relatively high. In the human genome, the number of IncRNAs is four times greater than that of coding RNAs ${ }^{[54]}$. Second, IncRNAs are highly expressed in the plasma, tissue and exosomes of cancer cases ${ }^{[55]}$. Third, IncRNAs have complex biological functions and are closely related to tumorigenesis and development. Therefore, IncRNAs may be promising biomarkers for the early detection and prognosis of various cancers ${ }^{[56]}$.

In the present meta-analysis, a total of 42 eligible studies were screened. The aggregated results of sensitivity, specificity, positive likelihood ratio, negative likelihood ratio, diagnostic odds ratio, and SROC AUC indicated that the abnormal expression of circulating IncRNAs exhibits a high accuracy for the diagnosis of SC. The ßestimate in the HSROC model indicated that the SROC is symmetrical. Meanwhile, the estimate of lambda reflected the diagnostic accuracy of IncRNAs. Sensitivity analysis verified the stability of the results, and the Deeks funnel chart asymmetry test showed that there was no obvious publication bias. The Fagan diagram also shows its advantages in clinical application, which was mainly due to its moderately high positive and negative predictive value.

For the obvious heterogeneity in the pooled estimates, many analyses have been applied to explore the source of heterogeneity. The ROC plane suggests the absence of a threshold effect, while the Galbraith star charts and bivariate boxplots suggest heterogeneity between studies. Meta-regression and subgroup analysis showed that the heterogeneity might come from the type of IncRNA: when IncRNA UCA1 was used as the grouping condition, the $I^{2}$ of sensitivity was reduced to $83.60 \%$, and the $\mathrm{I}^{2}$ of specificity was reduced to $45.20 \%(P=0.161)$. In addition, the diagnostic value of IncRNA UCA1 was above average (AUC: 0.92 (95\% Cl: $0.84-0.99)$ versus 0.83 (95\% Cl: 0.80-0.86)). There was no evidence that race, pathological types of experimental groups, pathological types of control groups, sample size, specimen type, and dysregulated state of IncRNAs significantly affected the pooled results.

Although meta-analysis of IncRNAs in the diagnosis of SC has been reported before ${ }^{[57,58]}$, most of them focus on IncRNAs in SC tissues. Although IncRNAs in tissue also have high diagnostic accuracy (AUC $=0.755^{[57]} ; 0.80^{[58]}$ ), their 
clinical application value is limited for the following reasons: first, the diagnosis of SC after surgery depends on the pathological morphology and immunohistochemical analysis, and the auxiliary role of IncRNAs is optional; second, in regard to endoscopic biopsy specimens, the diagnosis of SC still depends on the pathological morphology, and no extra tumor tissue can be used to extract IncRNAs. In contrast, circulating IncRNAs are ideal biomarkers due to their convenience and low invasiveness. Therefore, the present study on the application of circulating IncRNAs in the diagnosis of SC has greater clinical significance.

Nevertheless, this meta-analysis possessed some limitations. First, this systematic review and meta-analysis lacks eligible non-Asian studies. Second, almost every study focuses on different IncRNAs, and it was difficult to perform subgroup analysis based on IncRNA types to explain the possible sources of heterogeneity. Third, obvious heterogeneity was found in the included studies. Although diagnostic meta-analysis suggested that the type of IncRNA was a source of heterogeneity through meta-regression and subgroup analysis, the heterogeneity of sensitivity and specificity were still high in each subgroup.

\section{Conclusions}

In conclusion, the findings of the diagnostic meta-analysis provide evidence that circulating IncRNA tests exhibit a high accuracy for diagnosing SC, which is promising in clinical application due to their high positive and negative predictive value. This study provides an important reference value for the application of circulating IncRNAs as biomarkers for the early diagnosis of SC. Due to potential limitations, further investigations are warranted to verify the diagnostic role of circulating IncRNAs in SC.

\section{List Of Abbreviations}

\begin{tabular}{ll} 
LncRNA & Long noncoding RNA \\
\hline SC & Stomach cancer \\
\hline SROC & Summary receiver operating characteristic \\
\hline AUC & Area under the curve \\
\hline Cl & Confidence interval \\
\hline CA-153 & Cancer antigen 153 \\
\hline CEA & Carcinoembryonic antigen \\
\hline QUADAS-2 & Quality Assessment of Diagnostic Accuracy Studies 2 \\
\hline HSROC & Hierarchical summary receiver operator characteristic
\end{tabular}

\section{Declarations}

\section{Ethics approval and consent to participate}

Not applicable.

\section{Consent for publication}

Not applicable. 
Availability of data and material

All relevant data are within the paper and its additional files.

\section{Competing interests}

The authors declare that they have no competing interests.

\section{Funding}

The current study was supported by grants from 2019 Kunshan Key R\&D Plan (Ecological Agriculture and Social Development)-Social Development Science and Technology Project (KS1941), and Medical clinical science and technology development fund project of Jiangsu University (JLY20160040).

\section{Authors' contributions}

Investigation: Yongwei Hu.

Methodology: Jianhao Xu, Fang Cao.

Supervision: Houzhong Ding, Xiaojun Shen.

Writing - original draft: Fang Cao, Zaichang Chen.

Writing - review \& editing: Wei Han, Weijie Lu.

\section{Acknowledgements}

The current study was supported by grants from 2019 Kunshan Key R\&D Plan (Ecological Agriculture and Social Development)-Social Development Science and Technology Project (KS1941), and Medical clinical science and technology development fund project of Jiangsu University (JLY20160040).

\section{References}

1. Rawla P, Barsouk A. Epidemiology of gastric cancer: global trends, risk factors and prevention. Prz Gastroenterol 2019, 14(1): 26-38.

2. Zhang X, Liang W, Liu J, Zang X, Gu J, Pan L, Shi H, Fu M, Huang Z, Zhang Y, Qian H, Jiang P, Xu W. Long noncoding RNA UFC1 promotes gastric cancer progression by regulating miR-498/Lin28b. Journal of experimental \& clinical cancer research : CR 2018, 37(1): 134.

3. Jeddi F, Soozangar N, Sadeghi MR, Somi MH, Shirmohamadi M, Eftekhar-Sadat AT, Samadi N. Nrf2 overexpression is associated with P-glycoprotein upregulation in gastric cancer. Biomed Pharmacother 2018, 97 : 286-292.

4. Jemal A, Bray F, Center MM, Ferlay J, Ward E, Forman D. Global cancer statistics. CA: a cancer journal for clinicians 2011, 61(2): 69-90.

5. Kim DH, Oh SJ, Oh CA, Choi MG, Noh JH, Sohn TS, Bae JM, Kim S. The relationships between perioperative CEA, CA 19-9, and CA 72-4 and recurrence in gastric cancer patients after curative radical gastrectomy. Journal of surgical oncology 2011, 104(6): 585-591. 
6. McFadden EJ, Hargrove AE. Biochemical Methods To Investigate IncRNA and the Influence of IncRNA:Protein Complexes on Chromatin. Biochemistry 2016, 55(11): 1615-1630.

7. Jiang H, Guo S, Zhao Y, Wang Y, Piao HY, Wu Y, Zhang J. Circulating long non-coding RNA PCGEM1 as a novel biomarker for gastric cancer diagnosis. Pathology, research and practice 2019, 215(10): 152569.

8. Ren N, Jiang T, Wang C, Xie S, Xing Y, Piao D, Zhang T, Zhu Y. LncRNA ADAMTS9-AS2 inhibits gastric cancer (GC) development and sensitizes chemoresistant GC cells to cisplatin by regulating miR-233-3p/NLRP3 axis. Aging-Us 2020, 12(11): 11025-11041.

9. Hou J, Meng F, Chan LW, Cho WC, Wong SC. Circulating Plasma MicroRNAs As Diagnostic Markers for NSCLC. Front Genet 2016, 7: 193.

10. Walther S, Schuetz GM, Hamm B, Dewey M. [Quality of reporting of systematic reviews and meta-analyses: PRISMA (Preferred Reporting Items for Systematic reviews and Meta-Analyses)]. Rofo 2011, 183(12): 11061110.

11. Whiting PF, Rutjes AW, Westwood ME, Mallett S, Deeks JJ, Reitsma JB, Leeflang MM, Sterne JA, Bossuyt PM. QUADAS-2: a revised tool for the quality assessment of diagnostic accuracy studies. Ann Intern Med 2011, 155(8): 529-536.

12. Martindale JL, Wakai A, Collins SP, Levy PD, Diercks D, Hiestand BC, Fermann GJ, deSouza I, Sinert R. Diagnosing Acute Heart Failure in the Emergency Department: A Systematic Review and Meta-analysis. Acad Emerg Med 2016, 23(3): 223-242.

13. Liu W, Li Y, Zhang Y, Shen X, Su Z, Chen L, Cai W, Wang F, Ju S. Circulatinglong non-coding RNA FEZF1-AS1 and AFAP1-AS1 serve as potential diagnostic biomarkers for gastric cancer. Pathology, research and practice 2020, 216(1): 152757.

14. Yörüker EE, Keskin M, Kulle CB, Holdenrieder S, Gezer U. Diagnostic and prognostic value of circulating IncRNA H19 in gastric cancer. Biomed Rep 2018, 9(2): 181-186.

15. Liu Y, Jiang M, Ni LN, Xu Z, Xu JZ. Diagnostic value of serum carcinoembryonic antigen and carbohydrate antigen 724 combined with long non-coding RNA MALAT1 detection in gastric cancer. Cancer Research and Clinic 2019, 31(2): 88-92.

16. Hashad D, Elbanna A, Ibrahim A, Khedr G. Evaluation of the Role of Circulating Long Non-Coding RNA H19 as a Promising Novel Biomarker in Plasma of Patients with Gastric Cancer. J Clin Lab Anal 2016, 30(6): 1100-1105.

17. Li Q, Shao Y, Zhang X, Zheng T, Miao M, Qin L, Wang B, Ye G, Xiao B, Guo J. Plasma long noncoding RNA protected by exosomes as a potential stable biomarker for gastric cancer. Tumour Biol 2015, 36(3): $2007-2012$.

18. Liu Z, Shao Y, Tan L, Shi H, Chen S, Guo J. Clinical significance of the low expression of FER1L4 in gastric cancer patients. Tumour Biol 2014, 35(10): 9613-9617.

19. Liu J, Wang J, Song Y, Ma B, Luo J, Ni Z, Gao P, Sun J, Zhao J, Chen X, Wang Z. A panel consisting of three novel circulating IncRNAs, is it a predictive tool for gastric cancer? J Cell Mol Med 2018, 22(7): 3605-3613.

20. Lu Q, Yu T, Ou X, Cao D, Xie T, Chen X. Potential IncRNA diagnostic biomarkers for early gastric cancer. Mol Med Rep 2017, 16(6): 9545-9552.

21. Mohamed WA, Schaalan MF, Ramadan B. The expression profiling of circulating miR-204, miR-182, and IncRNA H19 as novel potential biomarkers for the progression of peptic ulcer to gastric cancer. J Cell Biochem 2019, 120(8): 13464-13477.

22. Piao HY, Guo S, Wang Y, Zhang J. Exosomal Long Non-Coding RNA CEBPA-AS1 Inhibits Tumor Apoptosis and Functions as a Non-Invasive Biomarker for Diagnosis of Gastric Cancer. Onco Targets Ther 2020, 13: 13651374.

Page $13 / 19$ 
23. Zhou H, Wang F, Chen H, Tan Q, Qiu S, Chen S, Jing W, Yu M, Liang C, Ye S, Tu J. Increased expression of longnoncoding RNA ZFAS1 is associated with epithelial-mesenchymal transition of gastric cancer. Aging (Albany NY) 2016, 8(9): 2023-2038.

24. Cai C, Zhang H, Zhu Y, Zheng P, Xu Y, Sun J, Zhang M, Lan T, Gu B, Li S, Ma P. Serum Exosomal Long Noncoding RNA pcsk2-2:1 As A Potential Novel Diagnostic Biomarker For Gastric Cancer. Onco Targets Ther 2019, 12: 10035-10041.

25. Zhou X, Yin C, Dang Y, Ye F, Zhang G. Identification of the long non-coding RNA H19 in plasma as a novel biomarker for diagnosis of gastric cancer. Sci Rep 2015, 5: 11516.

26. Elsayed ET, Salem PE, Darwish AM, Fayed HM. Plasma long non-coding RNA HOTAIR as a potential biomarker for gastric cancer. The International journal of biological markers 2018: 1724600818760244.

27. Xian HP, Zhuo ZL, Sun YJ, Liang B, Zhao XT. Circulating long non-coding RNAs HULC and ZNFX1-AS1 are potential biomarkers in patients with gastric cancer. Oncol Lett 2018, 16(4): 4689-4698.

28. Feng W, Zong W, Li Y, Shen X, Cui X, Ju S. Abnormally expressed long noncoding RNA B3GALT5-AS1 may serve as a biomarker for the diagnostic and prognostic of gastric cancer. J Cell Biochem 2020, 121(1): 557-565.

29. Fu M, Huang Z, Zang X, Pan L, Liang W, Chen J, Qian H, Xu W, Jiang P, Zhang X. Long noncoding RNA LINC00978 promotes cancer growth and acts as a diagnostic biomarker in gastric cancer. Cell Prolif 2018, $51(1)$.

30. Gao J, Cao R, Mu H. Long non-coding RNA UCA1 may be a novel diagnostic and predictive biomarker in plasma for early gastric cancer. Int J Clin Exp Pathol 2015, 8(10): 12936-12942.

31. Ghaedi H, Mozaffari MAN, Salehi Z, Ghasemi H, Zadian SS, Alipoor S, Hadianpour S, Alipoor B. Co-expression profiling of plasma miRNAs and long noncoding RNAs in gastric cancer patients. Gene 2019, 687: $135-142$.

32. Guo X, Lv X, Ru Y, Zhou F, Wang N, Xi H, Zhang K, Li J, Chang R, Xie T, Wang X, Li B, Chen Y, Yang Y, Chen L, Chen L. Circulating Exosomal Gastric Cancer-Associated Long Noncoding RNA1 as a Biomarker for Early Detection and Monitoring Progression of Gastric Cancer: A Multiphase Study. JAMA Surg 2020.

33. Arita T, Ichikawa D, Konishi H, Komatsu S, Shiozaki A, Shoda K, Kawaguchi T, Hirajima S, Nagata H, Kubota T, Fujiwara H, Okamoto K, Otsuji E. Circulating long non-coding RNAs in plasma of patients with gastric cancer. Anticancer Res 2013, 33(8): 3185-3193.

34. Ji B, Huang Y, Gu T, Zhang L, Li G, Zhang C. Potential diagnostic and prognostic value of plasma long noncoding RNA LINC00086 and miR-214 expression in gastric cancer. Cancer Biomark 2019, 24(2): $249-255$.

35. Lin LY, Yang L, Zeng Q, Wang L, Chen ML, Zhao ZH, Ye GD, Luo QC, Lv PY, Guo QW, Li BA, Cai JC, Cai WY. Tumororiginated exosomal IncUEGC1 as a circulating biomarker for early-stage gastric cancer. Mol Cancer 2018, 17(1): 84.

36. Pan L, Liang W, Fu M, Huang ZH, Li X, Zhang W, Zhang P, Qian H, Jiang PC, Xu WR, Zhang X. Exosomesmediated transfer of long noncoding RNA ZFAS1 promotes gastric cancer progression. J Cancer Res Clin Oncol 2017, 143(6): 991-1004.

37. Jin C, Shi W, Wang F, Shen X, Qi J, Cong H, Yuan J, Shi L, Zhu B, Luo X, Zhang Y, Ju S. Long non-coding RNA HULC as a novel serum biomarker for diagnosis and prognosis prediction of gastric cancer. Oncotarget 2016, 7(32): 51763-51772.

38. Zhao R, Zhang Y, Zhang X, Yang Y, Zheng X, Li X, Liu Y, Zhang Y. Exosomal long noncoding RNA HOTTIP as potential novel diagnostic and prognostic biomarker test for gastric cancer. Mol Cancer 2018, 17(1): 68.

39. Burock S, Herrmann P, Wendler I, Niederstrasser M, Wernecke KD, Stein U. Circulating Metastasis Associated in Colon Cancer 1 transcripts in gastric cancer patient plasma as diagnostic and prognostic biomarker. World $\mathrm{J}$ 
Gastroenterol 2015, 21(1): 333-341.

40. Ke D, Li H, Zhang Y, An Y, Fu H, Fang X, Zheng X. The combination of circulating long noncoding RNAs AK001058, INHBA-AS1, MIR4435-2HG, and CEBPA-AS1 fragments in plasma serve as diagnostic markers for gastric cancer. Oncotarget 2017, 8(13): 21516-21525.

41. Liu Y, Zhang YM, Ma FB, Pan SR, Liu BZ. Long noncoding RNA HOXA11-AS promotes gastric cancer cell proliferation and invasion via SRSF1 and functions as a biomarker in gastric cancer. World J Gastroenterol 2019, 25(22): 2763-2775.

42. Shan L, Liu C, Ma C. High Expression of Serum UCA1 may be a Potential Biomarker for Clinical Diagnosis of Gastric Cancer. Clin Lab 2019, 65(9).

43. Shao Y, Ye M, Li Q, Sun W, Ye G, Zhang X, Yang Y, Xiao B, Guo J. LncRNA-RMRP promotes carcinogenesis by acting as a miR-206 sponge and is used as a novel biomarker for gastric cancer. Oncotarget 2016, 7(25): 3781237824.

44. Yang Z, Sun Y, Liu R, Shi Y, Ding S. Plasma long noncoding RNAs PANDAR, FOXD2-AS1, and SMARCC2 as potential novel diagnostic biomarkers for gastric cancer. Cancer Manag Res 2019, 11: 6175-6184.

45. Xu H, Zhou J, Tang J, Min X, Yi T, Zhao J, Ren Y. Identification of serum exosomal IncRNA MIAT as a novel diagnostic and prognostic biomarker for gastric cancer. J Clin Lab Anal 2020: e23323.

46. Xu Y, Zhang G, Zou C, Gong Z, Wang S, Liu J, Ma G, Liu X, Zhang W, Jiang P. Long noncoding RNA DGCR5 suppresses gastric cancer progression by acting as a competing endogenous RNA of PTEN and BTG1. J Cell Physiol 2019, 234(7): 11999-12010.

47. Xu Y, Zhang G, Zou C, Qi W, Gong Z, Zhang G, Ma G, Zhang W, Jiang P. Long non-coding RNA LINC01225 promotes proliferation, invasion and migration of gastric cancer via Wnt/ $\beta$-catenin signalling pathway. J Cell Mol Med 2019, 23(11): 7581-7591.

48. Yang T, Zeng H, Chen W, Zheng R, Zhang Y, Li Z, Qi J, Wang M, Chen T, Lou J, Lu L, Zhou T, Dai S, Cai M, You W, Pan K. Helicobacter pylori infection, $\mathrm{H} 19$ and LINC00152 expression in serum and risk of gastric cancer in a Chinese population. Cancer Epidemiol 2016, 44: 147-153.

49. Zheng P, Zhang H, Gao H, Sun J, Li J, Zhang X, Gao L, Ma P, Li S. Plasma Exosomal Long Noncoding RNA IncSLC2A12-10:1 as a Novel Diagnostic Biomarker for Gastric Cancer. Onco Targets Ther 2020, 13: 4009-4018.

50. Zheng R, Liang J, Lu J, Li S, Zhang G, Wang X, Liu M, Wang W, Chu H, Tao G, Zhao Q, Wang M, Du M, Qiang F, Zhang Z. Genome-wide long non-coding RNAs identified a panel of novel plasma biomarkers for gastric cancer diagnosis. Gastric Cancer 2019, 22(4): 731-741.

51. Zhou Q, Li H, Jing J, Yuan Y, Sun L. Evaluation of C5orf66-AS1 as a Potential Biomarker for Predicting Early Gastric Cancer and Its Role in Gastric Carcinogenesis. Onco Targets Ther 2020, 13: 2795-2805.

52. Tan L, Yang Y, Shao Y, Zhang H, Guo J. Plasma IncRNA-GACAT2 is a valuable marker for the screening of gastric cancer. Oncol Lett 2016, 12(6): 4845-4849.

53. Schmitt AM, Chang HY. Long Noncoding RNAs in Cancer Pathways. Cancer cell 2016, 29(4): $452-463$.

54. Carninci P, Kasukawa T, Katayama S, Gough J, Frith M, Maeda N, Oyama R, Ravasi T, Lenhard B, Wells CJS. The transcriptional landscape of the mammalian genome. 309(5740): p. 1559-1563.

55. Liu L, Meng T, Yang XH, Sayim P, Lei C, Jin B, Ge L, Wang HJ. Prognostic and predictive value of long non-coding RNA GAS5 and mircoRNA-221 in colorectal cancer and their effects on colorectal cancer cell proliferation, migration and invasion. 2018: 1-17. 
56. Yang M, Wei W. SNHG16: A Novel Long-Non Coding RNA in Human Cancers. Onco Targets Ther 2019, 12: 11679-11690.

57. Hu QY, Zhao ZY, Li SQ, Li L, Li GK. A meta-analysis: The diagnostic values of long non-coding RNA as a biomarker for gastric cancer. Mol Clin Oncol 2017, 6(6): 846-852.

58. Cui Z, Chen Y, Xiao Z, Hu M, Lin Y, Chen Y, Zheng Y. Long noncoding RNAs as auxiliary biomarkers for gastric cancer screening: A pooled analysis of individual studies. Oncotarget 2016, 7(18): 25791-25800.

\section{Figures}

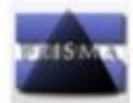

PRISMA 2009 Flow Diagram

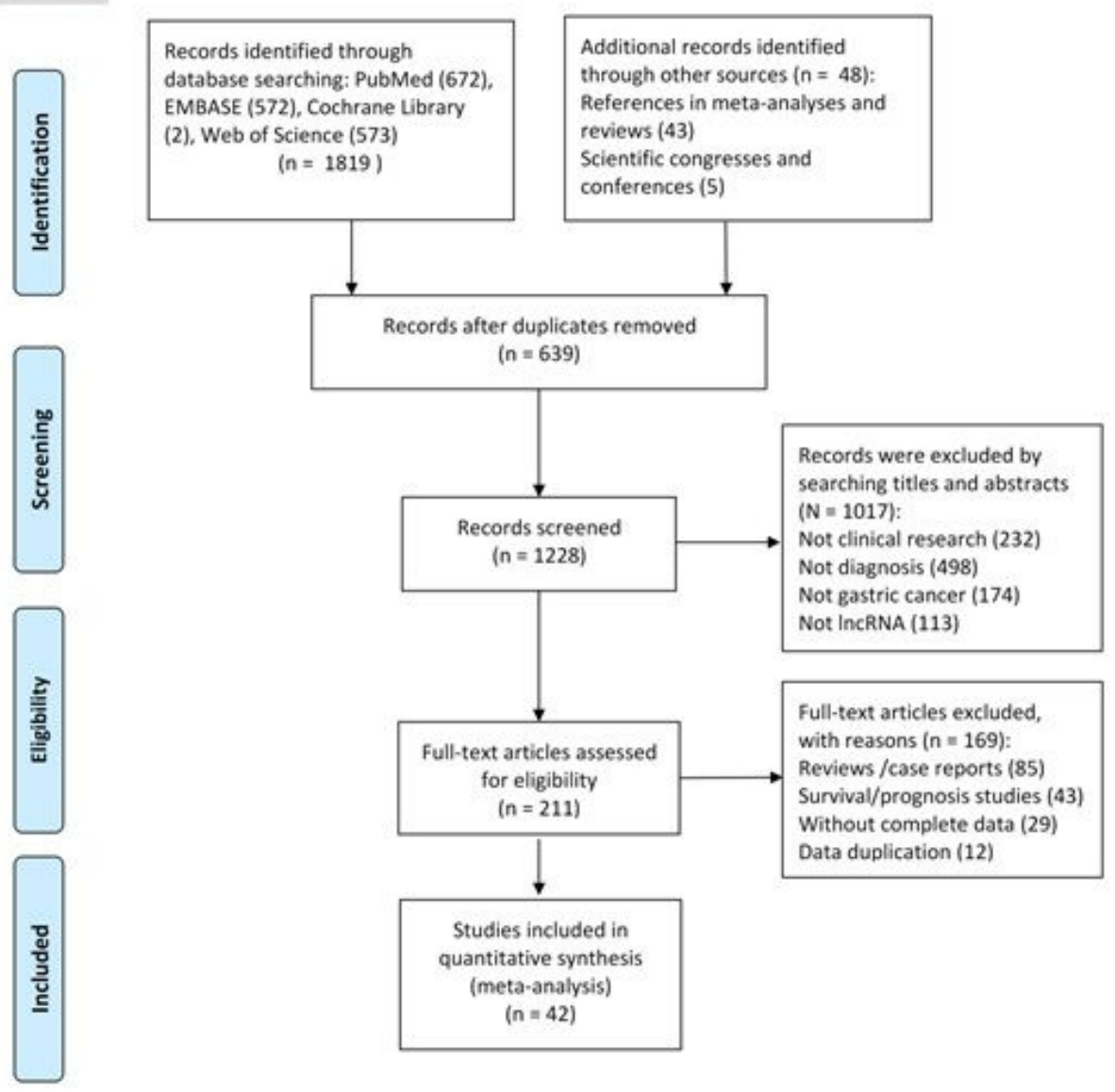

Figure 1

Flow chart of the study selection process. 


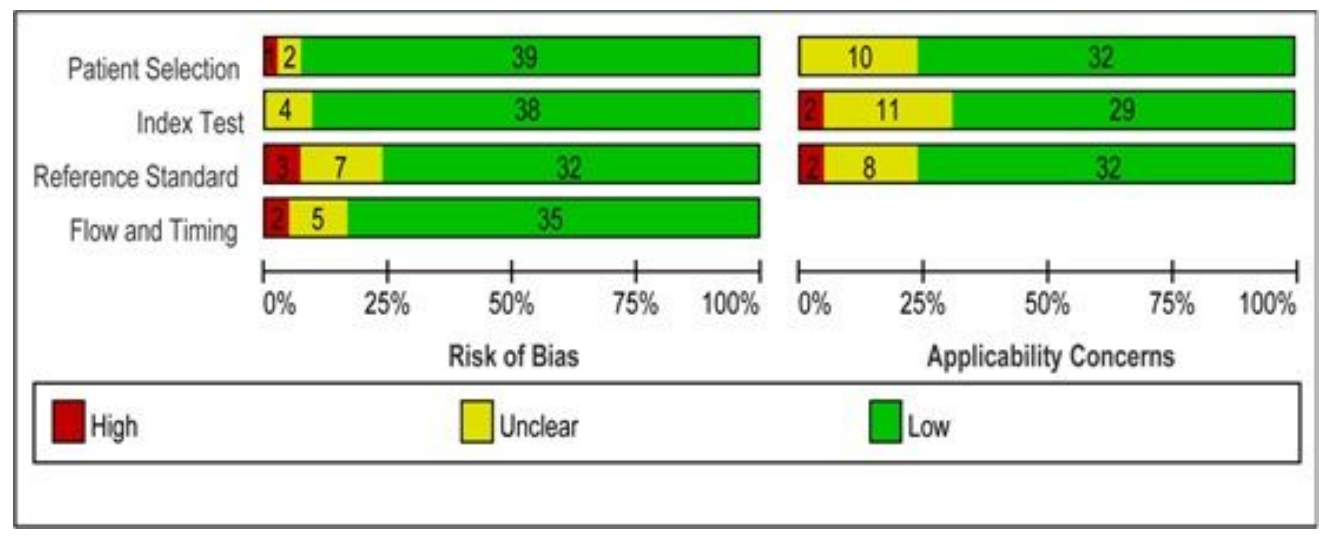

Figure 2

Quality assessment of eligible studies for diagnostic meta-analysis.

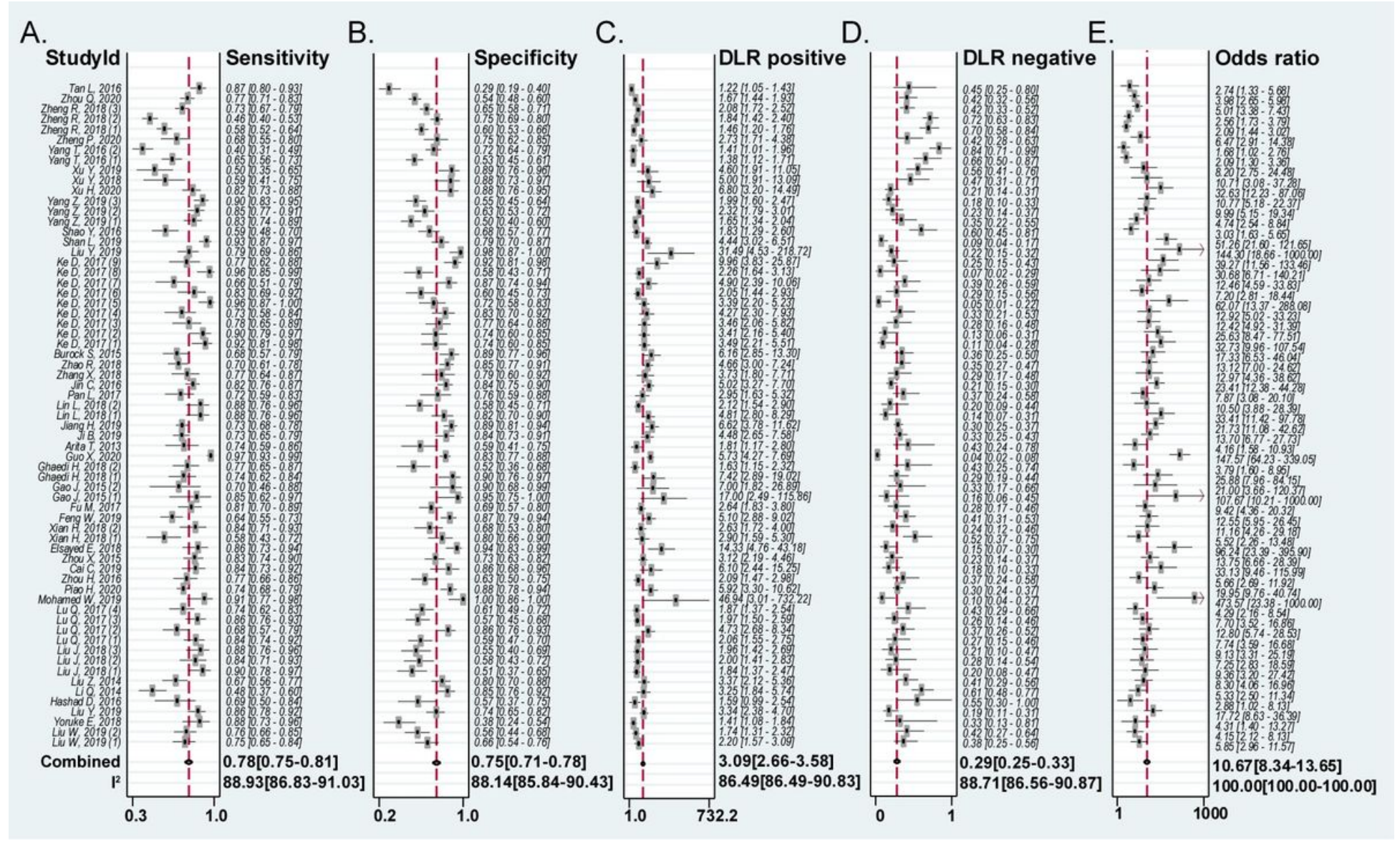

\section{Figure 3}

Forest plots of the diagnostic value for IncRNAs test in detecting SC. (A) Sensitivity, (B) Specificity, (C) Positive likelihood ratio , (D) Negative likelihood ratio, (E) Diagnostic odds ratio. 

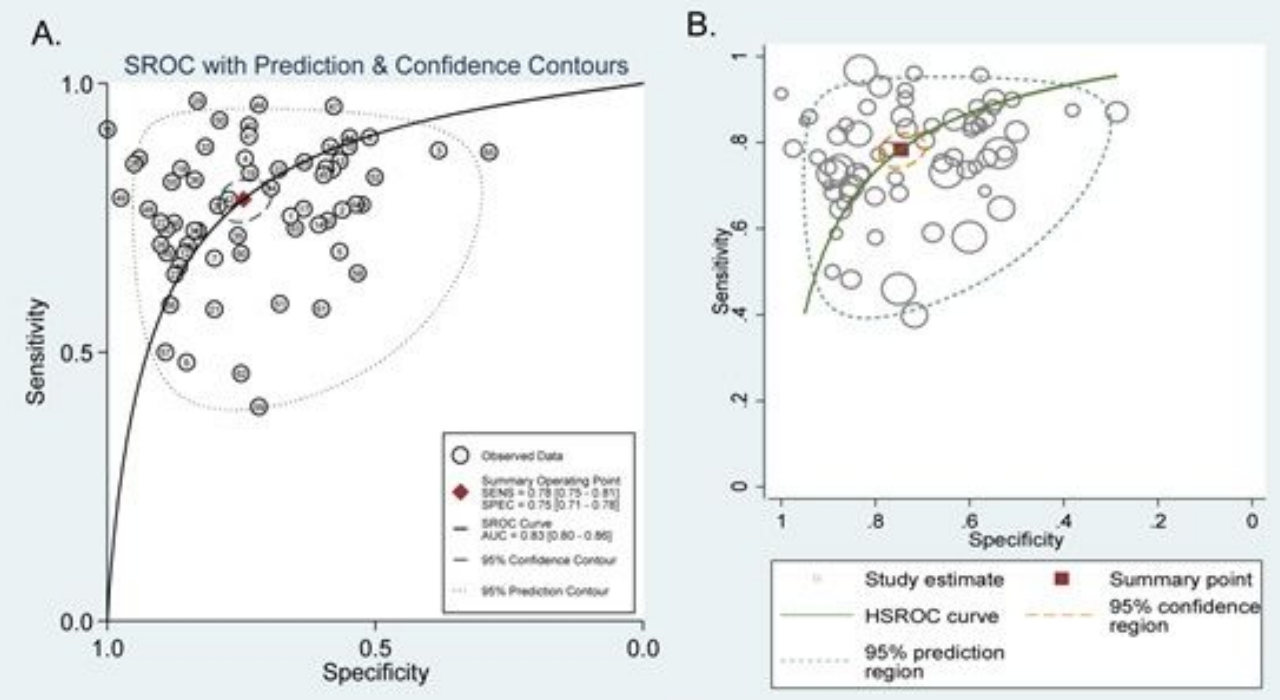

Figure 4

SROC curve of IncRNAs test in detecting SC. (A) SROC curve, (B) HSROC model.
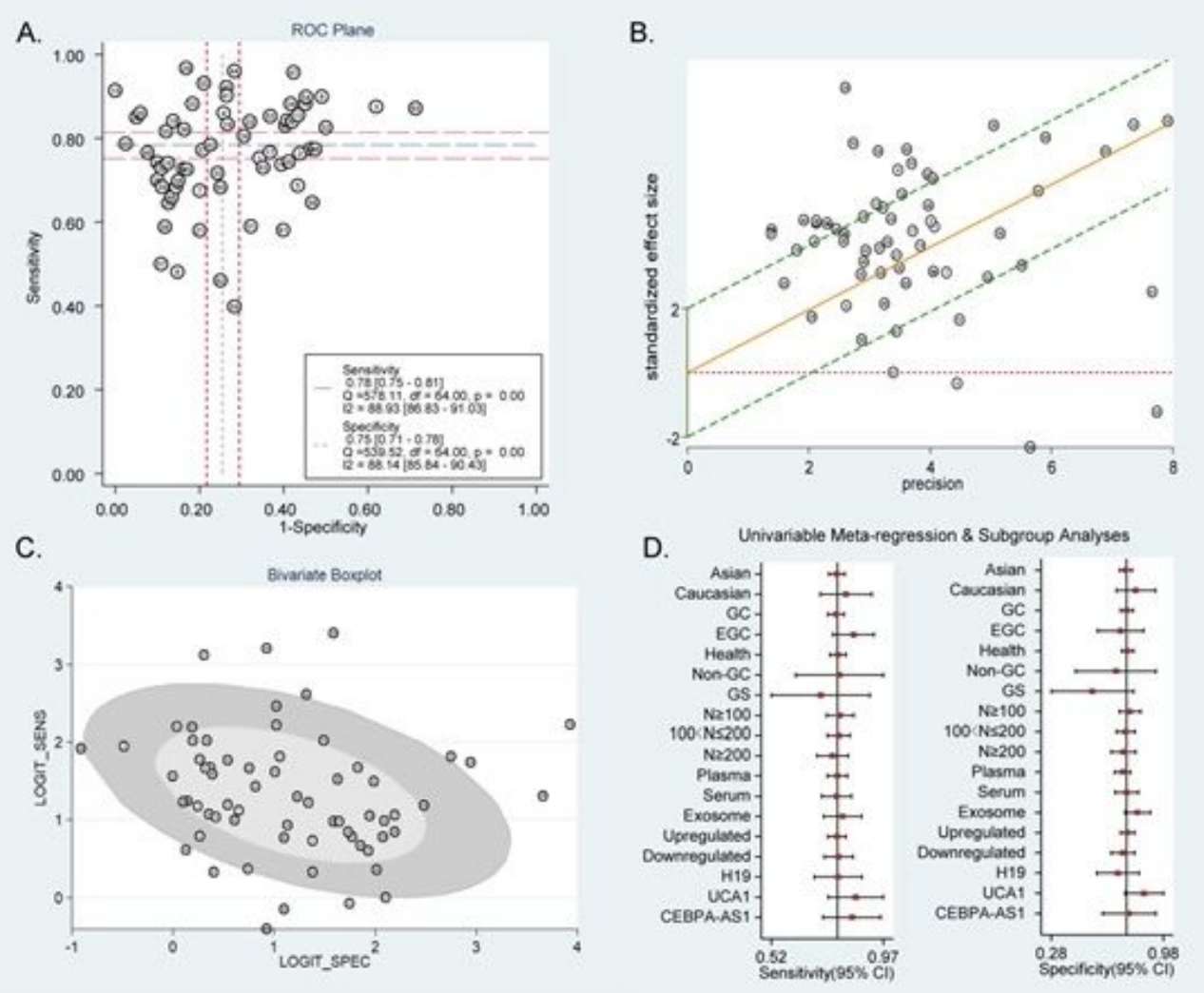

\section{Figure 5}

Heterogeneity analysis of diagnostic tests. (A) ROC Plane of the pooled studies. (B) Galbraith star charts of the pooled studies. (C) Bivariate boxplots of the pooled studies. (D) Subgroup and meta-regression analysis for heterogeneity of the pooled studies. 


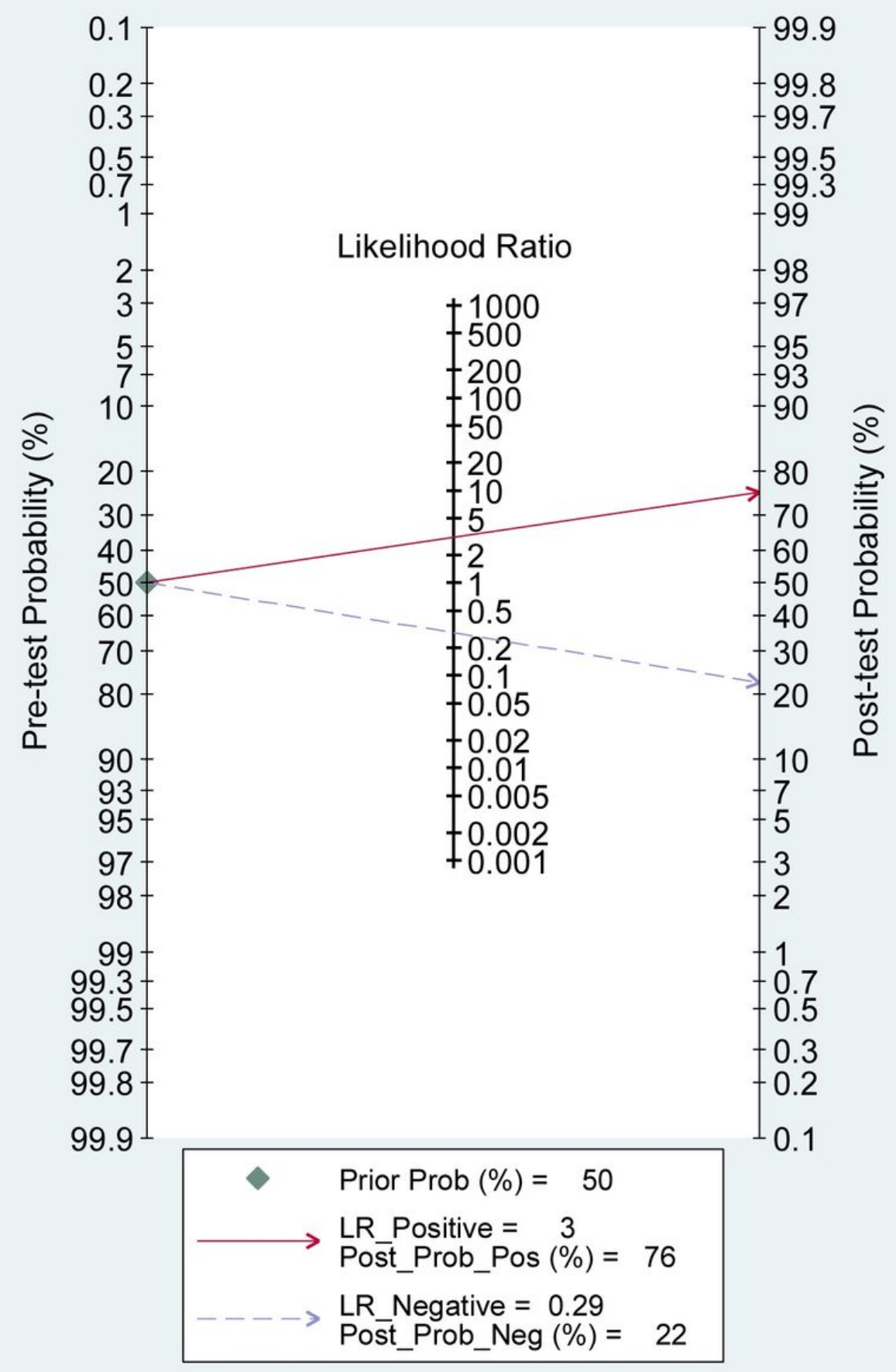

Figure 6

Fagan's nomogram of IncRNAs test in detecting SC.

\section{Supplementary Files}

This is a list of supplementary files associated with this preprint. Click to download.

- Additionalfile1.pdf

- SupplementaryFigure1.jpg 